DOI https://doi.org/10.36059/978-966-397-113-1/143-156

\title{
THE PUBLIC PROPERTY INSTITUTION IN THE MODERN SYSTEM OF GENERAL AND SPECIAL ADMINISTRATIVE LAW
}

\section{Zadyraka N. Yu.}

\section{INTRODUCTION}

The public property institution is connected with fundamental static administrative-legal categories in its essential characteristics. In fact, fundamental grounds of General administrative law establish the boundaries of public property legal protection and management in this field. At the same time, there is a situation when the subjects of public and private law, being the participants of administrative legal relations, for proper exercise of their powers require a basis for such activity which is, certainly, public property. This indispensable connection of institutional and material-financial categories of administrative law allows carrying out public management in the most effective way as a phenomenon of legal reality using all possible range of public administration activity tools.

In this case, there is a significant influence of Special administrative law on the public property institution, since for the implementation of relevant legal protection conditions, the specific regime features of property depending on the field of its use are involved. In essence, public property, as a rule, serves as a fundamental element for functioning of the most institutions of Special administrative law, determining the legal regime peculiarities of respective types of the said property. The state of things given is connected with the fact that public management in any field of public life is based on material and financial resources, which should meet the needs and interests of the subjects of public administration, on the one hand, and consumers of administrative services and public property users, on the other hand.

The urgency of the research topic is determined by the fact that as a result of the formation of new theoretical constructions in implementation of the public property legal regime, alternatives to public property in the form of powerful transnational corporations, etc. have begun to appear. In order to ensure an equitable transformation of public property management, the relations between the public property institution and 
fundamental components of Special administrative law taking into account public interest, rights and interests of wider population should be ensured. As a result, the public property legal regime may be restructured taking into account such characteristics as joint participation, pluralism, transparency and consistency.

\section{The Public Property Institution in the System of General Administrative Law}

Based on the content of legal norms regulating activity on public property use, it is possible to establish their public-legal (administrativelegal) nature. This will allow establishing the criteria for the correlation of administrative law constituent elements with a separate legal establishment in the form of a public property institution.

Taking into account the provisions above stated on institutionalization of a range of legal norms establishing the public property legal regime, one can agree with K. S. Belsky in the fact that evolution of public relations, which are the subject of administrative law legal regulation, is based on dynamic systemic-structural connections. At the same time, fast response to the conditions of surrounding environment, social needs etc. is taking place, which determines the appearance of changes in a relevant system ${ }^{1}$. From the perspective of the provisions stated on evolution of administrative law systematization, it is necessary to point out to the improvement of independent and integral nature of the general administrative law system by including the public property institution there as well. This will be ensured by resilience of administrative law norms regulating the public property legal regime and the dynamic orientation of the relevant law institution in the mobile system of General administrative law.

In general, one should proceed from the fact that theoretical provisions and general regulatory and general protection norms, united in the system of general administrative law, are characterized by universality, regular typical nature, and public management, organizational and functional generalization. The above mentioned features are used in highlighting the conceptual characteristics of administrative law, content manifestations of its norms and relations, and

\footnotetext{
${ }^{1}$ Бельский К.С. О предмете и системе науки административного права. Государство и право. 1998. № 10. С. 18-26.
} 
the regulation of public administration functions. The said legal regulators establish a generalized paradigm for realizing the administrative legal status of the relevant participants in administrative legal relations, forms and methods of public management, taking into account the requirements of lawfulness of such activity, including in terms of administrative discretion and administrative coercion use. First of all, implementation of these provisions is carried out through implementation of constitutional and legal norms in an orderly system of administrative law ${ }^{2}$. In essence, theoretical provisions and administrative legal norms on the establishment of legal regimes for various types of public property in relation to interaction of public administration bodies with each other and with private law subjects should be based on observance of principles of the supremacy of law and lawfulness, equality, legality and effectiveness.

Therefore, it can be stated that the public property institution is a part of the General administrative law system, primarily because of interconnectedness with its fundamental elements through the connection of theoretical provisions and administrative legal norms. The internal content of General administrative law allows setting of limits for substantial, institutional, functional and methodological manifestations of the practical implementation of public property legal regimes, in particular, taking into account customs, traditions and unwritten rules of conduct when using the latter. Alternatively, the hierarchical structure of these legal regulators allows unifying the substantive and procedural aspects of the relevant administrative relations taking into account the national interests of Ukraine and the public interest of participants in these relations.

In terms of the views expressed on the place of the public property institution in the system of general administrative law, one can agree with those scholars who support such an institutional affiliation ${ }^{3}$. Such conclusion is based on the provisions of Articles 142, 143 of the Fundamental Law of Ukraine on natural resources as public property, as

\footnotetext{
2 Шмідт-Ассманн Е. Загальне адміністративне право як ідея врегулювання: основні засади та завдання систематики адміністративного права / відп. ред. О. Сироїд ; пер. 3 нім. Г. Рижков, І. Сойко, А. Баканов. 2-ге вид., перероб. та доп. Київ : К.І.С., 2009. 552 с.

${ }^{3}$ Комзюк А.Т., Бевзенко В.М., Мельник Р.С. Адміністративний процес України: навч. посіб. Київ: Прецедент, 2007. 531 с.
} 
well as real estate as property, which ensures the functioning of public administration subjects ${ }^{4}$.

In material-financial dimension, the said public property must be used by public administration subjects for fulfillment of functions vested by law and conditions for its use by private law subjects to satisfy public interest. These postulates are primarily enshrined in constitutional norms, and are detailed in administrative legal norms concerning regulation of public relations on the practical implementation of the public property legal regime. The norms of private (civil) law may also be applied subsidiary to establish certain institutional and functional aspects of public property use by private law subjects.

We should note that the additional argument for attribution of the public property institution to the system of general administrative law is, for example, the German practice of administrative and legal regulation in the field of use of "public administration property", "public financial property", "public property that is in common use". At the same time, administrative legal norms governing the public property use in Germany, determine the use of both movable and immovable property in order to ensure fulfillment of functions of public administration bodies. In the given perspective, the utilitarian purpose of such property should be taken into account, including the use of natural resources, buildings, ammunitions, documentation, finance, public shares (equity shares) in economic partnerships, etc. Thus, the regulatory dimension of the public property institution is based on the accumulation of capital necessary for the fulfillment of the goal and tasks of public administration, as well as private law subjects involved in administrative legal relations on public property use. Definitely, such public property should directly or indirectly promote the exercise of public interest. The attribution of the public property institution to the general administrative law system is determined by the fact that the procedure for implementing the mechanism of administrative and legal support, use, transfer of such property, in particular, in public legal succession, has a clearly expressed administrative and legal nature. At the same time, in Ukraine the same procedural aspects of relations concerning implementation of the public property legal regime are not fully regulated at the legislative level.

\footnotetext{
${ }^{4}$ Конституція України: Закон від 28.06.1996 р. № 254к/96-ВР: із зм. і доп. станом на 30.09.2016 p. Офіційний вісник Украӥни. 2010. № 72/1. Спеціальний випуск. С. 15. Ст. 2598.

${ }^{5}$ Hans P. Lehrbuch der Verwaltung. Berlin-Göttingen-Heidelberg. Springer-Verlag. 1949. 560 s.
} 
For instance, legal regulators of the procedure for enforced collection of the property of communal enterprises by a state executive are established only in the letter of the Ministry of Justice of Ukraine ${ }^{6}$, which by its nature can not be considered as a source of administrative law at all. In fact, in Ukrainian realities, the legal status of public property is not fully defined, which does not contribute to the sustainability of implementation of regime characteristics and understanding of the place and purpose of public property in the system of law, in particular administrative one. The same situation leads to abuses and conflicts in using public property. Thus, according to the media, in Ukraine there are various "schemes" of appropriating public property by hostile takeovers, lease with subsequent privatization or illegal privatization of such property immediately ${ }^{7}$. In this regard, one must realize that the main problem is lack of a sufficient basis of administrative law regulators to implement constitutional provisions on public property and public management in the field of its use. In fact, the law does not even establish the definition of the public property legal category or provide the detailed procedure for its use by public and private law subjects. As a rule, only certain manifestations of the legal regime for certain public property types are established. In this regard, the Soviet traditions of public management of such property continues to prevail which are not effective enough. This state of things deprives the private law subjects as representatives of Ukrainian people's will of the right to real use of public property, in particular natural resources, infrastructure objects, etc.

Based on the provisions concerning the place of public property in the system of General administrative law, the main milestone in improving the system-structural characteristics of the said property and understanding the purpose of the institution mentioned above should be the focus on the "vertical" orientation. In this regard, E. B. Steison focused on taking into account descriptive, analytical and evaluation characteristics of historical realities, organizational structure and

\footnotetext{
6 Щодо порядку звернення стягнення на майно комунальних підприємств : лист Міністерства юстиції України від 27.12.2004 № 25-32-3644 URL: http://www.uazakon.com/document/fpart56/ idx56067.htm (дата звернення: 07.05.2019).

7 Щодо порядку звернення стягнення на майно комунальних підприємств : лист Міністерства юстиції України від 27.12.2004 № 25-32-3644 URL: http://www.uazakon.com/document/fpart56/idx56067 .htm (дата звернення: 07.05.2019).
} 
functions, in particular quasi-legal ones, etc ${ }^{8}$. The described criterion allows taking into account the material-procedural dimension of the public property institution when establishing the fundamental aspects of the legal regime functioning of the latter. In material terms, the purpose of this institute takes into account theoretical generalizations in part of the agreed competence of public administration and the establishment of a prevailing state policy on the public property management. Such standards should, in particular, be agreed with the constitutional guidelines and provisions of administrative legal norms, which refer to the clear formulation of the procedure for state policy implementation, conditions and procedures for a public administration activity, administrative discretion, etc. Alternatively, the procedural aspect of the purpose of the public property institution is based on the renewal of the current and prospective plan, including taking into account the institutional features of public property.

In foreign doctrine, the doctrinal approach is prevalent, according to which the purpose of the public property institution is appropriate to consider through the prism of categories of liquidity, managerial involvement and profitability ${ }^{9}$. Thus, liquidity can adequately and fully illustrate the specified characteristics of public finances in terms of transactions with such public property, time parameters of payments and the mechanism for attracting additional funds. On the contrary, managerial involvement is more universal category and can reveal the purpose of the public property institution in the system of General administrative law concerning the needs in time and managerial efforts necessary to ensure proper legal protection and defense of public property. The main thing here is the economic coloring of relevant publicmanagerial processes, taking into account the profitability of public property use by public and private law subjects. When describing the category of profitability, it should be noted that it has a prospective and retrospective orientation, since it is connected with the consideration of the previous, current and future situation when using public property. As a rule, this criterion is especially relevant when reflecting the long-term purpose of public property, in particular, related to increasing of its

\footnotetext{
${ }^{8}$ Stason E. B. Jr. Research in Administrative Law. Faculty Publications. 1964. Paper 1111. Pp. 99-107 URL: http://scholarship.law.wm.edu/facpubs/1111 (дата звернення: 07.05.2019)

9 Narula S., Singla M. Empirical Study on Non Performing Assets of Bank. International Journal of Advance Research in Computer Science and Management Studies. 2014. Vol. 2. Issue 1. Pp. 194-199.
} 
investment attractiveness and implementation of profitable projects based on the use of relevant public property.

Thus, it can be stated that the purpose of the public property institution in the system of General administrative law should be based not only on the institutional and procedural aspects of public administration functioning. It is also necessary to take into account the role of public property in the activities of private law subjects. It is worth noting that the approach that deals with the provision of a hierarchical dimension, professionalism in terms of functionality and impartiality is prevalent in the European doctrine on this subject ${ }^{10}$. This allows ensuring the rights of participants in administrative legal relations that are not the subjects of public administration, including users of public property as well as consumers of administrative services. In this regard, the public property institution should lay the foundation for a transparent and inclusive decision-making process in defining the relevant state policy. Thus, the purpose of the studied legal institution is focused on the material-procedural criteria of a "vertical" dimension based on the idea of human-centrism. The formulated criteria, in turn, will promote the institutionalization of the system of public administration bodies involved in public property management which is organized, meritocratic and "bound" by law requirements, as well as the involvement of interested private law subjects that act as participants in administrative legal relations in public property use. In fact, such state of things will ensure satisfaction of the public interest in improving the stability of economic situation and taking into account the needs and legitimate interests of the participants in the said administrative legal relations.

Based on the provisions stated above on the criteria for the formation and purpose of the public property institution in the system of General administrative law, it should be emphasized that this legal establishment, through a combination of homogeneous administrative legal norms aimed at establishing a public management procedure in regulated homogeneous administrative legal relations, acts as the very part of the branch of law mentioned. The described type of administrative legal relations on public property use is one of the key positions for the practical implementation of other institutes of General administrative law, mainly of theoretical orientation. At the same time, it concerns the implementation of all

\footnotetext{
${ }^{10}$ Kagan E. Presidential Administration. Harvard Law Review. 2001. No. 114. Pp. 2245-2385.
} 
constituent elements of administrative law. Such relatively isolated group of relevant administrative legal norms establishes the areas of functioning of administrative law general and special institutes. Therefore, it is about the whole range of administrative legal relations and, in particular, the implementation of public property legal regimes.

\section{Correlation of Special Administrative Law with the Public Property Institution}

Administrative-legal dimension of public management contributes to globalization and denationalization of administration powers in Europe ${ }^{11}$. Europeanized administrative law is aimed at the implementation of "competing" lawfulness ${ }^{12}$, demonstrating the consideration of legal regulators developed at the central (national) level and fragmentation in the implementation of these provisions in the field of public property use. In fact, it is about the unified dimension of the most significant limits of the practical implementation of the public property institution and decentralization during the implementation of the public property legal regime when it is used within the functioning of legal institutes of Special administrative law. The described dispersion of the administrative law system is compensated at the same time by orientation of its legal institutions to the protection and defense of rights, freedoms and legitimate interests of a person as a central subject of administrative law and a participant in administrative legal relations.

The mentioned recent globalization trends in administrative law development mean gradual disappearance of the boundaries between the legal status of public and private law subjects in administrative legal relations. This leads to a fundamental change in the system-structural characteristics of both General and Special administrative law. Such tendency is also becoming stronger as a result of an increase in comparative orientation of Special administrative law caused by continuous trans-boundary processes of harmonizing the standards of administrative legal activity and improving the quality and efficiency of public administration, in particular, in the field of public property. It is not less important to realize that the category of proportionality can set limits

\footnotetext{
${ }^{11}$ Rose-Ackerman S. Comparative Administrative Law: Outlining a Field of Study. Windsor Yearbook of Access to Justice. 2010. Vol. 28. No. 2. Pp. 435-449.

${ }^{12}$ Kagan R.A. Adversarial Legalism. The American Way of Law. Cambridge, MA : Harward University Press, 2003. $352 \mathrm{p}$
} 
for eliminating the boundaries between the public and the private in establishing regime aspects of public property use. At the same time, the significance of bureaucratic procedures which are traditionally crucial for European administrative law decreases in terms of "service nature" of public management.

The described globalization trends in administrative law development clearly indicate the possibility of improving the state policy in the field of public property use, including on the basis of institutional characteristics of Special administrative law. As A. Aman explains, global administrative law can make its contribution to the formation of a "political" society, creating a space for democratic debate ${ }^{13}$. For the functioning of the public property legal institution the indicated fact means that the unity of state policy will promote public inclusiveness. This will increase the freedom of exercise of authority in public property use, as well as lead to the full process of involvement of private law subjects in changing such policies in case of necessity. The said policy should acquire procedural qualities, taking into account public interest, the need to ensure pluralism and subsidiarity in the implementation of the public property legal regime.

Thus, the continuous development of the state policy on public property and renewed economic-political and legal realities of its use, it is possible to propose an inexhaustible list of areas in which a symbiosis of the legal norms of the institutes of General and Special administrative law acts. Thus, in global dimension, through the legal norms included in the system-structural establishments of the Special administrative law, there is an impact on the general-oriented legal norms of the public property institution in the following areas:

- Administrative and political (international relations, internal affairs, justice etc.);

- Public and managerial in relation to customs affairs, natural resources, security provision, information provision, state control;

- Business, economic, in particular agricultural and industrial;

- Social, socio-cultural (educational, scientific, art, sport, tourism, etc.);

- Inter-branch, including management of individual industries (security, defense, transport, healthcare, education, etc.) and inter-branch

${ }^{13}$ Aman A.C. The Democracy Deficit. Taming Globalization Through Law Reform. NY: NYU Press, 2004. $253 \mathrm{p}$. 
management (pricing, accounting and statistics, standardization, metrology, etc.), etc.

The modern stage in the administrative law systematization is primarily aimed not at establishing the procedures and order for the implementation of public management activities ${ }^{14}$, but at regulating the relevant administrative relations. The criterion for distinguishing these two approaches can be "the depth of legal regulation"15. For the proper and legitimate implementation of provisions of the public property institution, it is necessary to take into account its dynamic nature regarding the subjective, objective and substantial characteristics of the corresponding administrative legal relations. Statics of public property relations should reflect the nature and types of legal regulators of public property relations, as well as the practice of their application by administrative courts. It is also important, when using public property, to regulate the legal guarantees of good practice in administrative legal relations between people as the main subjects of administrative law, between private law subjects and public administration. Such tendency is typical of European administrative law and, taking into account European integration processes, and is extremely relevant for Ukraine.

In this view, public property as an object of public ownership can be perceived as a resource basis for the establishment of effective ways of public development using generally accessible objects to take into account the common benefit ${ }^{16}$. At the same time, taking into account the institutionalization of the place of the public property institution in the system of Special administrative law, the substantive dimension of the legal regime for the use of such property should be considered as the right of civil society to exercise competence directly or through public administration in respect of property that is generally accessible, nonexclusive and not disputable, as well as to exercise legal protection and defense of this property, its interests, public benefits, etc. These relations are formed during public management of specific objects for direct or indirect practical exercise of public interests by public and private law subjects, as a rule, using infrastructure objects and public resources ${ }^{17}$. The

\footnotetext{
14 Елистратов А.И. Основные начала административного права. 2-е изд. Москва: Г.А. Леман и С.И. Сахаров, 1917. 294 с.

15 Мельник Р.С. Система особливої частини адміністративного права України: якій їй бути сьогодні? Юридична Україна. 2008. № 2. С. 23-27.

16 Мазаев В.Д. Публичная собственность в Росии: конституционные основы. Москва: ОАО «Издательский дом «Городец», 2004. 384 с.

17 Там само.
} 
category of publicity influences the teleological characteristics of public property, which means, respectively, the use of public and power tools for the exercise of competence in public property. The latter also takes into account the legal regimes of public property on the substantial criterion, characterized by an axiological orientation in satisfying the interests and needs of all members of society.

In the context of the stated provisions on the influence of systemic and structural establishments of Special administrative law on the public property institution, it is also necessary to clarify that all these areas of society life allow regulating administrative legal relations properly as for public property use. Obviously, these are purely public-managerial relations, but a whole range of substantive and procedural relations between public administration bodies and private law subjects with regard to the implementation of the public property legal regime. In this sense, one can partly agree with R. S. Melnyk in the following that through the provisions of Special administrative law differentiation between the respective groups of administrative-legal norms is achieved ${ }^{18}$. At the same time, the latest globalization trends in the formation of the administrative law system, in particular the institutionalization of legal regulators of public property, do not allow supporting in full the thesis on the exclusive differentiation of the corresponding administrative legal relations. It is necessary to achieve an optimal balance between the universal provisions regarding the functioning of the public property legal regime and the peculiarities of certain types of administrative legal relations in the system of Special administrative law.

However, Special administrative law should influence the public property institution primarily through the concept of sustainable development. It is connected with the fact that in developed and developing countries, urban and rural areas are undergoing rapid urbanization. It is the result of natural, socio-cultural and economic changes, population growth in the global perspective, consumption and exhaustion of natural resources, and an increase in the level of environmental pollution. Often such changes take place in connection with public property use. In this regard the foreign doctrine states that sustainable development should ensure the physical, social and psychological environment. In this context, human behavior is

18 Мельник Р.С. Система адміністративного права України: дис. ... доктора юрид. наук: 12.00.07 / Харківський національний університет внутрішніх справ. Харків, 2010. 417 с. 
harmoniously adapted to integration as well as dependence on the natural factor for improving and preventing adverse effects for present and future generations ${ }^{19}$. Establishing the influence of constituent elements of Special administrative law on the public property institution, it is necessary to focus on the fact that considering the concept of sustainable development can improve the quality of life and take into account public interest. In this perspective it is about the motives and legitimate interests of public administration bodies that manage such property, private law subjects as users of public property and consumers of relevant administrative services, as well as subsequent generations who will use the property mentioned. It can be manifested contextually and causally in political, economic, social, cultural, etc. perspectives of a naturally oriented active (public-management) orientation to ensure the long-term development of civil society, taking into account national interests. The ways to achieve the proposed situation may include measures to increase public inclusiveness and involvement of private law subjects in formulation of the state policy in the area of establishing a public property legal regime, in particular forums.

\section{CONCLUSIONS}

One can state that the place and purpose of the public property institution in the system of General administrative law are aimed at institutional-procedural aspects of public administration functioning and ensuring the hierarchical dimension and impartiality of public law subjects using public property. In fact, General administrative law absorbs the public property institution in connection with the general orientation of the legal norms of this establishment, including the interaction with private law subjects in public property use. Such systemic-structural links allow guaranteeing the effectiveness of a public administration activity in the exercise of its powers, taking into account the public property legal regime based on unified standardization norms and rules of conduct.

A special administrative law forms the space for the implementation of the procedural component of the public property legal regime. Through the concept of sustainable development, fundamental characteristics of this property can be determined taking into account not only the national public interest, but also the trends of global supranational administrative

\footnotetext{
19 Brandon P.S., Lombardi P. Evaluating Sustainable Development in the Built Environment. NY : Wiley-Blackwell, 2011. 280 p.
} 
law. The legal norms covered by the system of Special administrative law establish the dynamics of public property relations, which, in particular, affects the content of the legal category of public administration subjects' liability in the administrative legal relations mentioned.

\section{SUMMARY}

The article deals with the criteria for the formation and purpose of the public property institution in the system of General administrative law. It is proved that the attribution of the public property institution to the system of General administrative law is determined by the procedure for the implementation of the mechanism of administrative and legal support, use, transfer of such property having a clearly expressed administrative and legal nature. In addition, the correlation between the public property institution and the fundamental components of Special administrative law taking into account public interest, rights and interests of wider population was considered. An attempt was made to reveal the specificity of influence of Special administrative law on the public property institution through the concept of sustainable development.

\section{REFERENCES}

1. Бельский К.С. О предмете и системе науки административного права. Государство и право. 1998. № 10. С. 18-26.

2. Елистратов А.И. Основные начала административного права. 2-е изд. Москва: Г.А. Леман и С.И. Сахаров, 1917. 294 с.

3. Комзюк А.Т., Бевзенко В.М., Мельник Р.С. Адміністративний процес України: навч. посіб. Київ: Прецедент, 2007. 531 с.

4. Конституція України: Закон від 28.06.1996 р. № 254к/96-ВР: із зм. і доп. станом на 30.09.2016 р. Офіиійний вісник Украӥни. 2010. № 72/1. Спеціальний випуск. С. 15. Ст. 2598.

5. Мазаев В.Д. Публичная собственность в Росии: конституционные основы. Москва: ОАО «Издательский дом «Городец», 2004. $384 \mathrm{c}$.

6. Мельник Р.С. Система адміністративного права України: дис. ... доктора юрид. наук: 12.00.07 / Харківський національний університет внутрішніх справ. Харків, 2010. 417 с.

7. Мельник Р.С. Система особливої частини адміністративного права України: якій ій̆ бути сьогодні? Юридична Україна. 2008. № 2. С. 23-27. 
8. Хміль О. ВР спростила привласнення держмайна. URL: http://www.epravda.com.ua/publications/49b7a00b9a76f (дата звернення: 07.05.2019).

9. Шмідт-Ассманн Е. Загальне адміністративне право як ідея врегулювання: основні засади та завдання систематики адміністративного права / відп. ред. О. Сироїд ; пер. 3 нім. Г. Рижков, І. Сойко, А. Баканов. 2-ге вид., перероб. та доп. Київ : К.І.С., 2009. 552 с.

10. Щодо порядку звернення стягнення на майно комунальних підприємств : лист Міністерства юстиції України від 27.12.2004 № 25-32-3644 URL: http://www.uazakon.com/document/fpart56/ idx56067.htm (дата звернення: 07.05.2019).

11. Aman A.C. The Democracy Deficit. Taming Globalization Through Law Reform. NY: NYU Press, 2004. 253 p.

12. Brandon P.S., Lombardi P. Evaluating Sustainable Development in the Built Environment. NY : Wiley-Blackwell, 2011. 280 p.

13. Hans P. Lehrbuch der Verwaltung. Berlin-Göttingen-Heidelberg. Springer-Verlag. 1949. $560 \mathrm{~s}$

14. Kagan E. Presidential Administration. Harvard Law Review. 2001. No. 114. Pp. 2245-2385.

15. Kagan R.A. Adversarial Legalism. The American Way of Law. Cambridge, MA : Harward University Press, 2003. 352 p.

16. Narula S., Singla M. Empirical Study on Non Performing Assets of Bank. International Journal of Advance Research in Computer Science and Management Studies. 2014. Vol. 2. Issue 1. Pp. 194-199.

17. Rose-Ackerman S. Comparative Administrative Law: Outlining a Field of Study. Windsor Yearbook of Access to Justice. 2010. Vol. 28. No. 2. Pp. 435-449.

18. Stason E. B. Jr. Research in Administrative Law. Faculty Publications. 1964. Paper 1111. Pp. 99-107 URL: http://scholarship.law. wm.edu/facpubs/1111 (дата звернення: 07.05.2019)

\section{Information about the author: Zadyraka N. Yu. PhD in Law Science,} Associate Professor at the Administrative Law Department, Faculty of Law, Taras Shevchenko National University of Kyiv 